\title{
Research Overview of M-Commerce Customer Satisfaction Measurement
}

\author{
Liping Liu * \\ Wuhan Technology and Business University \\ Wuhan, China \\ e-mail: 51441858@qq.com \\ * Corresponding Author
}

\author{
Jun Wang \\ Wuhan Technology and Business University \\ Wuhan, China \\ e-mail: $1075045780 @ q q . c o m$
}

\begin{abstract}
Started with the main evaluation model of customer satisfaction, this paper sorts out the research on mobile commerce customer satisfaction measurement: the related research on the influence factors of acceptance willingness of mobile commerce; the related research on customer satisfaction model of online shopping; the related research on the influence factors of customer satisfaction in mobile commerce and the related research on the evaluation system of mobile commerce service quality. Through quantities of document researches, there were few ones directly on $M$ commerce customer satisfaction measurement system and most were theoretical researches. It especially focus on induction about the factor index of customer acceptance of mobile commerce. And then it points out some research directions for measurement of M-commerce customer satisfaction in the future: For establishing the M-commerce customer satisfaction measurement system; the measurement of M-commerce customer satisfaction; classified measurement of M-commerce customer satisfaction; research of relationship between $M$ commerce customer satisfaction and customer loyalty.
\end{abstract}

Keywords-overview; customer satisfaction;neasurement; MCommerce;

\section{RESEARCH ON CUSTOMER SATISFACTION MEASUREMENT MODELS}

\section{A. Sweden Customer Satisfaction Barometer Model (SCSBM)}

Customer Satisfaction Index (CSI) is a novel quality assessment index which is being studied and used positively in many countries recently. Sweden built the first nationlevel measurement system of customer satisfaction in 1989. In the models of SCSB, customer satisfaction was postulated as the outcome variable for customer expectation and perceived value on products or services and as the cause variable of customer loyalty and customer complaint, among which customer expectation is exogenous variable, while the others are endogenous variables.

\section{B. Measurement Model of American Customer Satisfaction Index (ACSI)}

As an econometric model, ACSI adds an endogenous variable of perceived quality based on SCSB and can be used to measure the performance in enterprises, industries, sectors and national economy. ASCI model holds that, customer satisfaction has something to do with the pre-sale expectancy and after-sale performance of related products or services. The customer satisfaction may contribute to two basic outcomes: customer complaint and customer loyalty. In the model of ACSI, there would be 6 construct variables, 15 observation variables and 9 relations (observation variables here refer to variables that can be directly investigated). Among these 6 construct variables, customer expectancy and customer perception on quality and value are cause variables to customer satisfaction; customer complaint and customer loyalty are outcome variables of customer satisfaction.

\section{Measurement Model of European Customer Satisfaction Index (ECSI)}

By referring to ACSI model and adding the image as a construct variable in ECSI model, the model of European Customer Satisfaction Index (ECSI) divides perceived quality into two parts: perceived hardware quality and perceived software quality, of which the customer complaint is removed. For a tangible product, perceived hardware quality refers to the quality of product itself and perceived software quality refers to the quality of its services. And for a service product, perceived hardware quality refers to the quality of service attributes and perceived software quality refers to a number of factors relating to customer interactions in the service process, including language, behavior, and attitude of service providers as well as the environment of service place, etc.

\section{Measurement Model of Chinese Customer Satisfaction Index}

By adopting ACSI and ECSI for reference, Chinese Customer Satisfaction Index (CCSI) model is a quality measurement method with Chinese characteristics, which is established based upon China's conditions. Based on different products (or services), Chinese Customer Satisfaction Index could be mainly divided into the following few types: customer satisfaction model of nondurable consumer goods, customer satisfaction model of durable consumer goods, customer satisfaction model of the service industry and customer satisfaction model of government utility, etc. Each of them could be further divided upon different products. 
By large amounts of statistical data for repeated verifications and improvements, the measurement model of Chinese Customer Satisfaction Index is established based upon consumer psychology and customer praxiology. CCSI covers 7 construct variables: expected quality, brand image, perceived quality, perceived value, customer satisfaction, customer complaint and customer loyalty, in which the brand image is an endogenous variable and the others are exogenous variables.

\section{RESEARCH ON INFLUENCING FACTORS OF ACCEPTANCE WILLINGNESS IN M-COMMERCE}

The customer acceptance willingness of M-commerce has a direct important impact on customer satisfaction, so it is necessary to conduct a research on influencing factors of acceptance will in M-commerce. It covers the following contents.

\section{A. Theoretical Basis of Acceptance Intention}

\section{1) Theory of Reasoned Action (TRA)}

The theory of reasoned action is recognized as one of the most influential theories in researches of cognitive behaviors and behavior decisions. As known for "theory of reasoned action" as well, it has been widely applied in the prediction of various social behaviors. Derived from social psychology, theory of reasoned action was put forward jointly by American scholars Fishbein and Ajzen. This theory focuses on the attitude formation process based on cognitive information, and is mainly employed to analyze how does the attitude influence the individual behaviors.

\section{2) Theory of Planned Behavior (TPB)}

As the most famous theory of attitude and behavior relation in social psychology, the theory of planned behavior is also one of the most common theories in the researches of acceptance behaviors in the information system. Because theory of reasoned action is subject to its fundamental assumption, that is to say, individual behaviors are in the control of the will, it has imposed great restrictions on applicability of this theory. For this reason, Ajzen proposed theory of planned behavior by adding a variable named as "perceived behavioral control" to the theory of reasoned action in 1985.

\section{3) Innovation Diffusion Theory (IDT)}

Innovation diffusion theory was firstly put forward by American scholar gers in 1983. It probes into the promotion and diffusion process in social system of a novel thing, such as a novel concept, finding and fashion. The theoretical guiding ideology herein is before innovation. For this reason, some people are more open-minded than others, so they would rather accept the innovation.

\section{4) Research on Technology Acceptance Model}

a) Technology Acceptance Model (TAM)

TAM was advanced in 1989 by Davis et. al. They applied the theory of reasoned action in social psychology into management information system as well as explained and predicted the human acceptance extent to the information technology by taking factors of underlying belief, subjective attitude, behavior intention and external variables into consideration.

\section{b) Technology Acceptance Extension Model (TAM2)}

Thanks to the continuous and intensive researches made by scholars, the technology acceptance model has achieved great developments and improvements. The attitude towards the using was abandoned gradually by researchers, which they believed is directly influenced by the perceived usefulness and perceived ease of use. Davis abandoned the attitude towards the using in primary model and constructed the amended technology acceptance model in 1996.

c) Unified Theory of Acceptance and Use of Technology (UTAUT)

Venkatesh et al proposed UTAUT based on 8 models including TAM. The performance expectancy corresponds to the perceived usefulness, while the effort expectancy corresponds to the perceived ease of use.

d) Comprehensive Model of the Perceived Usefulness and Perceived Ease of Use (TAM3)

Venkatesh and Bala selected general data of TAM determinant factor as the basis of an intervention measure and proposed determinant factor model of perceived usefulness and perceived ease of use. In this way, Venkatesh and Bala put forward the comprehensive model of the perceived usefulness and perceived ease of use - TAM3.

\section{B. Domestic Empirical Study of Acceptance Model}

Zhou Tao, Lu Yaobin, Zhang Jinlong (2009) integrated TIF Model and UTAUT Model to delve into the mobile banking user adoption behaviors. The model was eventually established on the basis of six variables: task characteristics, technical characteristics, performance expectancy, effort expectancy, social influence and convenient condition. It adopted LISREL8.7 to conduct path analysis, test model hypotheses and draw the conclusion stated below: both task characteristics and technical characteristics have exerted remarkable effects on the matching degree of tasks/technologies and then on behaviors of usage. Cheng Xiaolu (2013) derived performance expectancy, effort expectancy and social influence from UTAUT Model, added individual innovation and perceived cost, established a model with 5 variables investigates by method of questionnaire surveys, tests hypotheses and concludes that performance expectancy, effort expectancy and individual innovation were the 3 most important factors affecting acceptance intention.

Lan Ying (2010) built user attitude model of mobile advertising from entertainment, information, interference and individuation. Besides, considering social norm theory and technology acceptance model, Lan Ying also analyzed users' intention on using mobile advertising from enriching and internalization ingredients of social norms, perceived usefulness and perceived ease of use. Xiao Shuang (2013) established the user attitude model of mobile advertising from entertainment, information, interference, credibility, individuation and interactivity (a variable is added on the basis of Yan Ying) and also verified model and hypothesis by using empirical method. Liu Hongyan, Fu Shenglan 
(2014) delved into the mobile advertising acceptance attitude from the perspective of college students' mobile advertising experience, and by questionnaire surveys and hypothesis testing methods, they found out that perceived control, advertising rewards and social influence have positive impacts, perceived risk has negative, and perceived control has significant impacts on user acceptance intention for mobile advertising.

He Junhong, Mo Zan and Et al (2013) established the acceptance model in mobile marketing with technology factors, ease of use, usefulness and intention by integrating various technology acceptance models. The research found that the technology factors exert no direct influence, but exert indirect influence on intention by ease of use and usefulness.
Based on user acceptance behaviors of mobile marketing in a dynamic perspective, He Junhong, Liu Hongwei, Mo Zan divided factors influencing acceptance behaviors into initial behaviors influencing factors and continuous behaviors influencing factors. The initial behaviors influencing factors (including marketing factors, technology factors and consumer factors) exerted an influence on intention of initial behaviors, while continuous behaviors influencing factors (including perceived usefulness, perceived ease of use and satisfaction) exert influences on the intention of continuous behaviors and thus impact continuous behaviors.

TABLE I. COMPARATIVE ANALYSIS FOR VARIABLES OF DIFFERENT TECHNOLOGY ACCEPTANCE MODELS

\begin{tabular}{|c|c|c|c|}
\hline Research Field & Article Name & Theoretical Basis & Influencing Variable \\
\hline M-Commerce & $\begin{array}{l}\text { Research on M-Commerce User Acceptance } \\
\text { Model Based on UTAUT; } \\
\text { Empirical Research on Factors Influencing } \\
\text { Readers'Acception of Mobile Phone Books; } \\
\text { Research on the M-Commerce Behavior of } \\
\text { Usage on TAM and Network Externality }\end{array}$ & $\begin{array}{l}\text { TAM and theory of } \\
\text { network externality }\end{array}$ & $\begin{array}{l}\text { Performance Expectancy, Effort Expectancy, Social } \\
\text { Influence, Individual Innovation, Perceived Cost; } \\
\text { Performance Expectancy, Effort Expectancy, Social } \\
\text { Influence, Facilitating Condition, Behavior Intention, } \\
\text { Behavior of Usage, Perceived Cost; } \\
\text { Perceived Usefulness; Perceived Ease of Use, Behavior } \\
\text { of Usage, Intention of Use, Perceived Joy, Theory of } \\
\text { Network Externality, Communication Effectiveness, } \\
\text { Perceived Service Charge }\end{array}$ \\
\hline M-Advertising & $\begin{array}{l}\text { Research on Advertising Acceptance Model } \\
\text { of M-Commerce; } \\
\text { User Attitude Model to M-Advertising and } \\
\text { Its Empirical Research } \\
\text { Research on Marketing Factors for } \\
\text { M-Advertising Acceptance Willingness } \\
\text { from the Perspective of College Students' } \\
\text { Mobile Advertising Experience }\end{array}$ & $\begin{array}{l}\text { Social norm theory } \\
\text { and TAM; } \\
\text { TAM3; } \\
\text { TPB and UTAUT }\end{array}$ & $\begin{array}{l}\text { Social Enhancement Constituent, Social norm } \\
\text { Internalization Constituent, Usefulness Perception Ease } \\
\text { of Use Perception; } \\
\text { Entertainment, Information, Interference, Credibility, } \\
\text { Individuation, Interactivity; } \\
\text { Perceived Control, Advertising Rewards, Social Impact, } \\
\text { Perceived Risk }\end{array}$ \\
\hline M-Marketing & $\begin{array}{l}\text { Research on M-Marketing Acceptance } \\
\text { Model Based on Technical Impacts; } \\
\text { Research on Dynamic Evolution of } \\
\text { M-Marketing Consumer Acceptance } \\
\text { Behaviors; }\end{array}$ & $\begin{array}{l}\text { TAM; } \\
\text { TAM and theory of } \\
\text { dynamic evolution }\end{array}$ & $\begin{array}{l}\text { Technical Factors, Ease of Use, Usefulness, Intention; } \\
\text { Marketing Factosr, Technical Factors, Consumer } \\
\text { Factosr, Satisfaction, Usefulness, Ease of Use; }\end{array}$ \\
\hline M-Payment & $\begin{array}{l}\text { Research on M-Banking User Acceptance } \\
\text { Behaviors Integrating TTF and UTAUT; } \\
\text { Research on Factors Influencing M- } \\
\text { Payment Consumer Acceptance; }\end{array}$ & UTAUT and TAM3 & $\begin{array}{l}\text { Characteristic of Task, Characteristic of Technology, } \\
\text { Performance Expectancy, Effort Expectancy, Social } \\
\text { Influence, Convenient Condition; } \\
\text { Performance Expectancy; Effort Expectancy;Social } \\
\text { Influence ; Convenient Condition, Usage Intention, } \\
\text { Usage Situation, Perceived Risk;Perceived Usefulness, } \\
\text { Perceived Ease of Use,Compatibility, Perceived Risk }\end{array}$ \\
\hline $\begin{array}{l}\text { M-Location } \\
\text { Service }\end{array}$ & $\begin{array}{l}\text { Research on Influencing Factors for the } \\
\text { User Acceptation of Mobile Micro blog } \\
\text { based on UTAUT }\end{array}$ & UTAUT & $\begin{array}{l}\text { Performance Expectancy; Effort Expectancy; } \\
\text { Social Influence , Convenient Condition; Usage } \\
\text { Intention, Perceived Risk, Behavior of Usage }\end{array}$ \\
\hline E-Commerce & $\begin{array}{l}\text { TAM and Empirical Research on the B2B } \\
\text { E-Commerce System }\end{array}$ & UTAUT; & $\begin{array}{l}\text { Performance Expectancy; Effort Expectancy; } \\
\text { Social Influence ; Behavior Intention, Subjective Norm, } \\
\text { Work Correlation, Uncertainty Avoidance, etc. }\end{array}$ \\
\hline E-Government & $\begin{array}{l}\text { Research on Utility and Influence Factors of } \\
\text { Government Portal Website from User; } \\
\text { Research on the E-Government Innovation } \\
\text { Acceptance Model based on Integration of } \\
\text { TOE and UTAUT }\end{array}$ & $\begin{array}{l}\text { TAM31; } \\
\text { TOE and UTAUT }\end{array}$ & $\begin{array}{l}\text { Perceived Usefulness; Perceived Ease of Use; Behavior } \\
\text { of Usage, Intention of Usage, Characteristics of } \\
\text { Government Website, Subjective Norm, Perceived Risk, } \\
\text { Task-Technology Fit ;Performance Expectancy; Effort } \\
\text { Expectancy; Social Impact; Behavior Intention, } \\
\text { Behavior of Usage, Task-Technology Fit, Selectivity }\end{array}$ \\
\hline $\begin{array}{l}\text { Enterprise } \\
\text { Information } \\
\text { System }\end{array}$ & $\begin{array}{l}\text { User Acceptance Model Conducted by ERP } \\
\text { System and Its Empirical Research }\end{array}$ & $\begin{array}{l}\text { TAM and theory of } \\
\text { reasoned action }\end{array}$ & $\begin{array}{l}\text { Perceived Usefulness; Perceived Ease of Use, Attitude } \\
\text { Representation Acceptance, Perceived Compatibility, } \\
\text { Perceived Applicability, Self-Efficacy, Subjective Norm }\end{array}$ \\
\hline
\end{tabular}




\section{RESEARCH ON ONLINE SHOPPING CUSTOMER SATISFACTION MODEL}

To delve into the factors influencing the online shopping customer satisfaction, Zha Jinxiang and Wang Lisheng (2006) proposed the customer satisfaction model. It covers three variables: online customer expectation, online shopping perceived quality of service and online customer satisfaction. At the same time, it exerts impacts on online shopping perceived quality of service, such as website design characteristics, network security, personalized service, network interaction, product quality assurance, price advantage, and operation difficulty. For these eight aspects, the author believes that, online customer expectation and online customer satisfaction are negatively correlated, while online shopping perceived quality of service and online customer satisfaction are positively correlated. All these eight aspects of perceived quality of service positively influence on quality of service and thus positively influence on the customer satisfaction. Through the empirical analysis, the author made a test of significance for the above assumptions, wherein assumptions are all supported except from website design characteristics.

Lu Xia and Zhuang Xiaojiang (2010) divided the purchasing process of online customers into five periods: the induced demand, information collection, comparison of choice, purchase decision and evaluation after purchase. Based on the customer satisfaction, the author probed into the $\mathrm{B} 2 \mathrm{C}$ online marketing strategy and established the B2C online customer satisfaction model. In this model, the author took the trust as an intermediate variable to impact the customer satisfaction, while the prior expectation and perceived performance would directly determine the strength of customer trust. The customer prior expectation is determined by online convenience, information security, transaction reliability and the feeling of shopping. The online payment and delivery, humanization of website interface and other factors determine the size of performance perceived by customers.

By probing into the $\mathrm{C} 2 \mathrm{C}$ E-Commerce customer satisfaction, Xu Donglei and Wang Zuzhu (2010) pointed out that the influencing factors of customer satisfaction come from the following five ways: platform feature, online situation, pre-sale and after-sale service, transaction payment, and logistics distribution. The platform feature refers to the friendliness of website design, the convenience of classification retrieval, the stability of web server and the quality of website information. The online situation covers the type, updating speed, price, conformance and clear classification of goods. The pre-sale and after-sale service refers to the response to customer inquiries, the replacement of goods, the personalized services and the creditworthiness of merchants. The transaction payment includes the transaction means and security and the protection of customer secrets. The logistics distribution refers to the distribution means and time as well as the integrity of parcels.

\section{RESEARCH ON INFLUENCING FACTORS OF M- COMMERCE CUSTOMER SATISFACTION MODEL}

Zhu Min (2012) pointed out that the influencing factors in B2C M-Commerce customer satisfaction model can be summarized for three aspects: brand image, E-Commerce platform quality and service quality and set a research model for influencing factors in $\mathrm{B} 2 \mathrm{C}$ M-Commerce customer satisfaction. By using the empirical analysis method for verification, this paper made the following conclusions. 1) The E-Commerce platform quality exerts a positive impact on customer satisfaction. Among the three factors of platform quality, the operation convenience and platform security positively impact the customer satisfaction and the impact extent of platform security is higher than that of operation convenience. 2) The service quality exerts a positive impact on the customer satisfaction. The ease of communication and convenience of process are two factors of service quality, exerting a positive impact on the customer satisfaction, wherein the impact extent of ease of communication is higher than that of convenience of process. 3) The brand image has no significant influencing relationship with the customer satisfaction.

Taking Meituan Network as an example for research on influencing factors of M-user satisfaction, Yang Fengfei (2013) concluded two factors influencing M-user satisfaction from the perspectives of online and offline: mobile client technology and service products of alliance merchants.

\section{RESEARCH ON M-COMMERCE SER VICE QUALITY EVALUATION SYSTEM}

Wang Mingming, Zhao Guowei (2015) conducted a research on B2B M-Commerce service quality evaluation system from 5 dimensions and 25 index items based on the SERVQUAL Scale proposed by American scholar PZB, wherein these 5 dimensions refer to the tangibility, reliability, assurance, responsiveness and empathy. The Principal Component Analysis(PCA)method by SPSS software was used to make an exploratory factor analysis for sample data and eventually transformed 5 dimensions to 4 dimensions of security, responsiveness, empathy and tangibility. The reliability, validity and confirmatory factor analysis were then made to conclude that the fitting degree of B2B MCommerce service quality evaluation model constructed by 4 dimensions is rather high.

Peng Runhua, Yang Zhendong (2011) delved into the establishment for mobile E-commerce service quality evaluation index system for mobile E-tourism. Upon the integration of indexes proposed by numerous scholars, evaluation indexes mainly include the correction of transaction records, service universality, ease of connection, ease of system usage, promptness, interactivity, business scale and reputation, accuracy of business information, transaction fairness, confidentiality of transaction information, speediness of transaction confirmation, reliability, network security and other indexes. By inducting and reorganizing the documentary indexes, 24 index problems were thus designed to form an original scale for measurement of the mobile E-commerce service quality 
evaluation index system for mobile E-tourism and written questionnaires of experts were carried out to use PCA and maximum variance rotation method by SPSS software for analysis. The result has demonstrated that, these 5 principal components could explain the main effects of indexes and could be used as mobile E-commerce service quality evaluation index system for tourism. Eventually, a mobile Ecommerce service quality evaluation index system for tourism with 5 dimensions of reliability, convenience, responsiveness, mobile situationality and security as well as 16 secondary indexes was formed.

Through quantities of document researches, there were few ones directly on M-commerce customer satisfaction measurement system and most were theoretical researches.

$\mathrm{Xu}$ Jinhui (2008) formed the three-level measurement model for M-commerce customer satisfaction of our country based on American Customer Satisfaction Index (ACSI) model in his paper. In this model, the overall customer satisfaction is Level-1 index, customer expectation, perceived quality, perceived value, extent of customer satisfaction, customer loyalty and customer complaint are the Level- 2 indexes and the Level- 3 indexes can be measured by manifesting each Level-2 index.

Zhang Zhe (2010) had broadly defined the mobile electronic commerce as: an application of mobile terminal equipment and an electronic commerce activity conducted by the mobile Internet. She held that, compared with traditional electronic commerce, the mobile electronic commerce has its unique properties, whose mobility of equipment and coverage of mobile network enable users to free from the limitations of time and location. In this way, they would have more freedom to make commerce activities. Therefore, there are numerous factors influencing the M-commerce customer satisfaction and constructing an index system for $\mathrm{M}$ commerce customer satisfaction is complex. Integrating the features of $\mathrm{M}$-commerce customers and realities of $\mathrm{M}$ commerce market, the author has established a measurement index system for M-commerce customer satisfaction. The measurement indexes are product information, transaction security, marketing plan, product service, and enterprise image.

There are some research directions for measurement of M-commerce customer satisfaction in the future:

1)For establishing the M-commerce customer satisfaction measurement system: an M-commerce customer satisfaction measurement system should be established upon the special features of M-commerce to use SPSS, AMOS and other scientific approaches for tests of reliability, validity, and degree of fitting.
2)For the measurement of M-commerce customer satisfaction: the measurement of M-commerce customer satisfaction for those enterprises adopting the M-commerce should be conducted for the actual application.

3)For classified measurement of M-commerce customer satisfaction: some important factors out of numerous factors influencing the M-commerce customer satisfaction should be selected for special research, such as measurement of Mcommerce service quality and M-commerce initial trust.

4)For research of relationship between M-commerce customer satisfaction and customer loyalty.

\section{ACKNOWLEDGMENT}

(1)2015 Foundation Program of Humanities and Social Sciences Research of Education Bureau of Hubei Province(15G160)

(2) 2014 Opening Foundation Program of Hubei Commercial Service Development Research Center in Hubei College Humanities and Social Sciences Research Base (2014Y005)

\section{REFERENCES}

[1] Cheng Xiaolu. Research on Acceptance Model of Mobile Commercial Users Based on UTAUT. [D]. Zhejiang University, 2012.

[2] Zhou Tao, Lu Yaobin, Zhang Jinlong. Integrated Research of Mobile Bank Users' Acceptance Behaviors From TIF and UTAUT Perspectives [J] . Journal of Management, 2009 , 22 ( 3 ) : 75-82

[3] Lan Ying. Research on Advertising Acceptance Willingness Model Based on Mobile Commerce[D]. Southwest Jiaotong University, 2010: 20-25.

[4] Liu Hongyan, Fu Shengmei. Study on Marketing Factors Affecting Mobile Advertising Acceptance Willingness- Perspective from College Students' Mobile Advertising Experience [J]. Soft Science, 2014,28

[5] Cha Jinxiang, Wang Lisheng. Empirical research on influencing factors of online shopping customer satisfaction [J]. Management Science, 2006, 19 (1): 50-58.

[6] Lu Xia, Zhuang Xiaojiang. Analysis for B2C online marketing strategy based on customer satisfaction [J]. Commercial Times, 2010,(29): 3536.

[7] Li Zhong, Wang Zuzhu, Xu Donglei. Empirical research on influencing factors for $\mathrm{C} 2 \mathrm{C}$ E-Commerce customer satisfaction [J]. Information Research, 2011, (09): 51-54.

[8] Zhu Min. Research on influencing factors of customer satisfaction in B2C mobile electric commerce [D]. Suzhou University, 2012.

[9] Wang Mingming, Zhao Guowei. Research on the service quality evaluation system of B2B mobile electric commerce. [J], Science and Technology Management Research, 2015 (3): 142-145.

[10] Zhang Zhe. Research on measurement system for M-Commerce customer satisfaction [J].China Management Informationization. 2010, 13(20):47-48

[11] Huo Yingbao. Research on theory and application of customer sa tisfaction measurement [M]. Nanjing: Southeast University Press, 2010:80-93. 